\title{
A Comparative Research on Japanese Employment System Based on the Theories of David Marsden, James C. Abegglen and Ronald P. Dore
}

\author{
Sun Yan
}

\begin{abstract}
The theme of Japanese administration has been a hot topic debated during decades and scholars have done their researches in a various fields over this subject. There are three outstanding achievements in searching for the truth of Japanese employment system made by David Marsden, James Abegglen, and Ronald Dore on behalf of each period. Though numerous discussions have been done on each of their typical logics, there is still no study to string the three together. Of course theories of the three consider different periods, stand for different fields or even view from different perspectives, but they also show factors in common, and the meaning of comparative study lies in their key concepts on Japanese employment system.

As the title shows, this paper attempts to make a review based on the theories of the three in order to search for an integrated understanding of Japanese employment system through Marsden's framework, Dore's detailed data analysis, and Abegglen's cultural discussion. At the same time, the advantages and disadvantages of this system can be re-recognized and new ideas over Japanese administration will be sighted.
\end{abstract}

Index Terms-Common destiny, contractual custom, employment relationship, lifetime commitment.

\section{INTRODUCTION}

Scholars have done their researches in a various fields on the subject of employment system, centering on its concerns, types of systems, how it works and what it affects. No definition can be simply done to the theory of employment system because it differs in countries across the world, and shows diversity in employment relations. It, however, can be examined through different employment relationship adopted by different countries [1], on the aspects of organizational significance and social diversity.

There are three main parts in the paper done depending on the theories of the three professors. Fore and the most, the chief discussion of employment system lies in David Marsden's ${ }^{1}$ work "A theory of employment system: micro-foundation of social diversity", a latest work published in 1999. Throughout the work of Marsden, the

Manuscript received October 21, 2013; revised December 30, 2013.

Yan Sun is with the Shiga University, Japan (e-mail: smilesun527@yahoo.co.jp).

${ }^{1}$ David Marsden is presently a Reader in Industrial Relations at the London School of Economics. His career has also taken him to Aix-en-Provence, Trier, and Rome as a Visiting Professor. He has researched extensively on comparative industrial relations and labor markets, and he has worked with the ILO, the OECD, the European Commission, and the World Bank. He has also worked on public service pay reforms in different countries, and has recently completed a major study of the effects of performance related pay on employee motivation and productivity. topic that has been centered on is to explore the international diversity of employment relationship. He aims to solve the question of why there are such great differences in international employment relations and why firms and workers should take employment relationships as their economic cooperation basis. Flexibility in employment relationship not only provides the managers authority of organizing work, but also sets limitations on obligations of employees. As one of the preventative example in Marsden's discussion [2], Japanese employment system has been demonstrated according to this general theory.

It is universal acknowledged that the typical characteristics of Japanese administration have been first put forward by Abegglen ${ }^{2}$ in his book "The Japanese factory: aspects of its social organization" published in 1958. As his argument goes [3], these features are mainly divided into three aspects: 1) lifetime commitment; 2) seniority-based system, and 3) company union, which are well known as "Three Sacred Treasures of Japan" all over the world. From then on, the miraculous Japanese administration began to draw people's interest and how these characteristics work in the practices during daily management have been paid enough attention.

In 1973, British professor Ronald P. Dore ${ }^{3}$ made his book "British Factory--Japanese Factory: The Origins of National Diversity in Industrial Relations" published. This is the first work that concerns about the Japanese factory, exploring the real differences between two Japanese factories with two British ones that make similar products. Instead of contrasting Japanese employment relations with an ideal image of the western country, comparisons are done from point to point. Dore classifies the British employment system as market-oriented while the one in Japan as organization-oriented. More in details, comparison is pursued with vivid illustrations in the first half of the book,

\footnotetext{
2 James C. Abegglen (1926 - 2007) was a university professor in management and economics, the author and co-author of ten books on Japan He was one of the founders of the Boston Consulting Group (BCG) in 1963, and the first representative director of its Tokyo branch, founded in 1966. His academic interests centered on Japanese enterprises and economic systems and their priority to the Western capitalism.

${ }^{3}$ Professor Ronald P. Dore (born in 1925) is a British sociologist specializing in Japanese economy and society and the comparative study of types of capitalism. He is an associate of the Centre for Economic Performance at the London School of Economics and is a fellow of the British Academy, the Japan Academy, and the American Academy of Arts and Sciences. The citation for his eminent scholar award from the Academy of International Business describes him as "an outstanding scholar whose deep understanding of the empirical phenomena he studies and ability to build on it to develop theoretical contributions are highly respected not only by sociologists but also by economists, anthropologists, historians, and comparative business systems scholars".
} 
and later these assumptions are examined step by step. Different from Abegglen's attitudes towards Japanese administration, Dore's research contributes as a milestone for a positive direction [4].

In general, this thesis attempts to make a comparative study of international employment system on the basis of theories by Marsden, Abegglen and Dore in searching for the truth of Japanese administration through new perspectives by examining differences between Japanese and other countries, and on the other hand, for a new step forward in the academic field.

\section{SUBJECTS DEBATED IN MARSDEN'S THEORY: CONTRACTUAL CUSTOM}

\section{A. Employment Relationship}

\section{1) Employment relationship and opportunism}

The most immediate integrate to the phenomenon of employment system is considered to be the employment relationship that remains an eternal subject to researchers when discussions are done in the field of employment system. Up to now, people's attention is also attracted to a class of questions like what is employment relationship, how to build a reductive employment relationship, and something related.

Meaning can be given to the idea of employment relationship according to Marsden's theory-there are "two great innovations that lie behind the rise of the modern business enterprise: limited liability and the employment relationship" [1], which describes a framework or a structure of cooperation between employees and employers within the same corporation. This kind of employment relationship is composed of two parties, one of them being the employee and the other called the employer. Moreover, the environment they interact with each other deserves an equal importance. The relationship empowers management or managers to control or direct the employee in detailed tasks after they have been hired, which is considered as the key to the employment relationship; likewise, it also sets a kind of affiliation with which employees are willing to know how the work should be performed and do it as expected.

Thus, one aspect could be envisaged that both the employers and employees keep a standpoint to run after a stable employment relationship and benefit from it mutually because it costs a lot to find not only alternative workers but jobs.

However, in this context, the opportunism takes an opposite stand, claiming that it would be better for the managerial authority to be limited by a system of rules. For the employers, their authority tends to extend over a certain tasks, and the employee will agree to work on these tasks. In this way the problem of opportunism comes out obviously that the range of tasks has not been definite clearly. In addition, there are other domains of opportunism in the employment relationship between workers and enterprises, for example, the continuity of employment, variability of the business, as well as certification of skills.

In order to constitute a stable and sufficient employment relationship, two problems concerning about contractual limitations should be resolved. In other words, the system of rules mentioned above must accomplish two main objects: efficiency and enforceability. The former is the problem of providing appropriate measures to match the job requirements and worker skills under the employment contract. While the latter discusses the problem of giving a sufficiently robust criterion that can be easily applied in a variety of working environments in order to assign tasks to specific groups of workers, which will protect the flexibility of employers and limit the obligations of employees at the same time.

\section{2) Employment rules}

When obligations for both employers and employees are specified in details, unstable factors come to prominence. Similarly, the burden of a relationship of trust between them will be increased. If this is the case take place actually, the flexibility, playing a key role in employment relations, will be destroyed and the reciprocal relationship vanishes on its way. Trying to avoid these two issues in searching for a productive employment relationship, it is necessary to set up a series of rules.

In order to achieve the two limitations on contracts: efficiency and enforceability, two principle methods are identified in the first step. On the one hand, efficiency, for example, connecting jobs to works, and organizing tasks into jobs, will be achieved by a production approach or a training approach, which are significant approaches for matching abilities of workers to tasks. In the production approach, jobs are defined in required production tasks on a basis of complementary. While jobs defined based on complementary in workers' skills happens in the training approach. On the other hand, enforceability, regulating task allocation rules, can be divided into task-centered rules and function-centered rules. The task-centered rules designate the nature of assignments to individual workers; the function-centered rules establish a system to distribute tasks and workers into different categories.

So that, by integrating these efficiencies and enforceable categories to give space to the continuance of employment relationship, four types of employment rules begin to come into sight. They are known as work post rule, job territory or tool of trade rule, competence rank rule, and qualification rule that are shown in Table I.

TABLE I: THE CONTRACTUAL CONSTRAINTS AND COMMON EMPLOYMENT RULES

\begin{tabular}{llll}
\hline $\begin{array}{c}\text { The focus } \\
\text { enforcement criteria }\end{array}$ & of & \multicolumn{2}{c}{$\begin{array}{l}\text { Pob demands identified by: } \\
\text { approach }\end{array}$} \\
\hline $\begin{array}{l}\text { Task-centered } \\
\text { rule }\end{array}$ & 'Work post' rule 'Job territory'/ 'tool of trade' & & \\
\hline Function-/procedure-centered & \multicolumn{2}{c}{$\begin{array}{c}\text { 'Competence rank' rule } \\
\text { 'Qualification' rule }\end{array}$} \\
\hline
\end{tabular}

Source: David M. (1999), pp. 33.

\section{B. Applications of Classification Rules}

Different choices of employment rules across countries lead to social diversity, so judging from Marsden's point of view, the four types of employment rules, provide a 
foundation for international diversity in employment relationship. At the same time, this diversity in turn serves as a basis for the four modes of employment system. Thus far, five countries-Germany, Britain, America, French and Japan are selected as cases to conform to different systems of employment rules.

TABLE II: DOMINANT EMPLOYMENT RULES BY COUNTRY

\begin{tabular}{|c|c|c|}
\hline & $\begin{array}{c}\text { Production } \\
\text { approach }\end{array}$ & $\begin{array}{c}\text { Training } \\
\text { approach }\end{array}$ \\
\hline Tasks-centered rules & France, America & Britain \\
\hline Function-centered rules & Japan & Germany \\
\hline
\end{tabular}

Source: David M. (1999), pp. 118.

Due to Table II listed above and Table II contained in the first part of this chapter, it is obvious that Japan attempts to conform to the competence rank rule distinctly. In other words, the Japanese employment rule can be regarded as taking a production approach under a background of function-centered rules.

\section{Performance Management}

Japanese employment, applying to the production approach, keeps a standard of performance based on abilities. When talked about the direct personal responsibility, each job requests for job earnestness, but for the indirect team responsibility, Japan takes cooperation in team work or competence into serious consideration. Meanwhile, to the other aspect of contractual limitations, its influences on structures of the labor markets also wave with an equal attraction. Judging from the function-centered rules Japan has adopted, it can be defined as an internal labor market with a functional flexibility within the framework of production approach at the same time.

Account for the discussion that has been done above-mentioned, the dominant performance criteria dictated by the two contractual constraints becomes clear. Taking the enforceability constraint first, there are two kinds of accountability to this element: the direct or individual one, and the indirect or group one.

As far as qualification rule concerns, initiative based on professional standard of being emphasized under indirect or group accountability. And it could be expected to be leading performance criterion according to the scope for initiative built on the skills.

\section{Pay and Incentives}

\section{1) Regular pay and compensations}

On the whole, Marsden takes a stand in confirming that in the payment system most Japanese corporations adopt a combination of length of service and merit pay. He takes a viewpoint that the employees' monthly remuneration is made up with base pay, which is primarily determined by length of service, the efficiency pay based on efficiency savings, as well as job and ability pay.

Allowances and supplements are also a component related to person, to the characteristics of the person, but this relation stands less obvious to the company's profits at that moment than workers' diligence and skills.

In Japan, compensation is paid due to the length of service [5]. Rather than individual performances, the point of assessment is centered on contributions to the team and the efforts made towards team activities. Japanese firms operating the competence rank system are primarily concerned with marginal performance that relates to cooperative work relations rather than an individual work post.

However, here again, is necessary to discuss the role of loyalty and trust in Japanese employment relationship discussed by Marsden, and this is a convincing argument that managers in Japanese factories do not bargain for their salaries because bargain for a rise goes against the whole ethos of the firm. Even if the request is asked, it won't be taken seriously; and even though it is treated seriously, the manager may be questioned for his loyalty to the firm and felt unwanted by the firm.

\section{2) Job classifications and performance pay}

Although it is possible for a company to set wage system based on performances rather the rules, due to a strong relation between wages and performances, both parties know that great efforts will sometimes not be paid back by high wages, and little effort may not be given punishment. Thus there will be objections from employees when wages seem uncertain or whether employers are reliable. Another meaning given to performance pay is that it is a method of encouraging employees to peruse additional pay by drawing out addition efforts. It is necessary to think about the problem of how much the pay will be, and shall it be determined before or after the hard effort [6].

Since it is not simple to make decision after the effort, a large number of firms assume a way of seniority-based pay. For example, in large Japanese corporations, seniority has been combined with merit, showing a shifting balance between the two principles over time. Even if good performance is rewarded according to management and focused on the ability to contribute to productivity, it is hard to implement because of the difficulty of rating employees and they are supposed to act fairly. Based on these points, the discretionary pay turns into seniority-based gradually.

Trainee pay is also paid in some countries, which refers to the wages that paid to workers during their training period. In many EU countries including Britain, France and Germany, an increasingly number of workers are likely to insist on rate-for-the-job rules because of their weak status differentiation circumstances. Thus it is not easy to low youth trainee rates of the pay. To this argument, Japan appears to be an exception. Internal labor markets have been great absorbers of young workers, and pay rates type institutions ${ }^{4}$. Here, however, thanks to the long-term employment relationship, skilled workers are protected from being substituted by young labors. Since a right balance number of young labors are entering into corporations, the firm helps not only to protect the job security for promoted senior workers, but also make it possible for them to get an increasing pay.

\section{E. Skill Development}

Different from other countries, Japan owns its special training approach. That is special training facilities and on the job training courses. 
1) As a member in the organizational problem-solving model, Japan prefers to acquire active participations of employees. It contents, for example, quality, circle, and ringing.

2) Job flexibility and job rotation also devote to a variation of training. Alternatively, it would be a question that what corresponds should the organization take to the occurrence of any uncertainty. But Japan seems to choose a simple answer that firm-specific skill has been incorporated into the training and organization for job rotations.

\section{RESEARChES DONE By ABEgGLEN: CONTRACTUAL CUSTOM}

\section{A. Comparison on Employment Relationship}

\section{1) Choice of lifetime commitment}

The issue of employment relationship has been an eternal topic when touching upon employment system. The difference of major employment relation between Japan and America is as like as an apple to an oyster. Japan adopts a relationship of lifetime employment formula; while the American one is practically based on contracts.

Due to the Japanese circumstance at that time, the background of carrying out a lifetime commitment can be summarized in three areas. Firstly, the pressure from labor movement is strong. Secondly, it is in great lack of labor force. And lastly, abuse of the right to dismiss also contributes to this aspect. The phenomenon of lifetime employment has been proved by its rare exceptions, and the permanent relationship between employees and corporations imposes obligations and responsibilities on both the factory and the worker of a different order [3].

This announces that no matter a work is at what level in Japanese factory, he commits himself a member of the factory since the entrance. In the case, the company will not discharge a worker unless in an extreme circumstance, and in turn, the worker will not quit the company for employment elsewhere.

In the case study made in Abegglen's research, Japanese companies take full responsibilities for continuous salary to all their employees during the employment. Hence, there is no doubt that workers in such companies are often termed "permanent" or "eternal" employees ${ }^{4}$. On the company's sake, both top-management and workers are standing in the same lifetime employment relationship, which is quite differs from the employment relationship built in American companies.

\footnotetext{
${ }^{4}$ The description of job relations given here is held to describe the genera rule in the large factories of Japan. In a few types of industries, notably in construction and shipbuilding, worker recruitment and interplant relations differ somewhat from those described in this research. Also, in the smaller and specialized shops of the large cities, movement of a worker from one another job is more common and accepted. In the textile industry, where the proportion of female employees is high, data on the rate of exit of female workers provides an apparent exception to the above rules. Since women are expected and encouraged to marry, even assisted in marriage, after five to seven years of employment and must leave the company at the time of marriage, the rate of employee exit is high, which does not, however, alter the nature of the commitment of worker and company through the employment period. (Abegglen, 13)
}

\section{2) Productivity of the system}

In the Japanese factory, there is always a surplus of labor force than required that maintains the level of production. This is readily admitted and commonly noted at the recent time. However, in American production, there is a greater part of unit cost which is usually presented as labor cost, because it intends to maximize the use of machine processes in production. In Japan, it is reverse, where the machine is something like luxury while the labor costs lower in productive unit.

This kind of immobility of labor affects seriously on both economic well-being and the Japanese nation, expressing mainly in two particular economic aspects. One problem is the process of technical innovation. As a result of usual existence of surplus of laborers, introducing new methods or machinery into production has been preserved. And this enhances a conservative attitude towards changes caused by innovation. However, when new technology is introduced, problems begin to take on the scene. For example, the present problem of labor surplus in Japanese factory will be exacerbated.

The other problem Japan has to do with is the impact of sudden economic change on the factory-"Dodge depression" [3]. Take the financial crisis took place during the period of occupation by America as an example, Japan made a back forward in economic activities. And even, there is no way to achieve any measure to improve flexibility of labor force with Japanese system though workers and management are willing to take their obligations to remain in the relationship.

Disadvantageously, labor cost per unit of production in Japan is rising and it is taking on a continuous trend of growth. In sharp contrast with the United States, the immobility of Japanese labor force influences considerably on not just the present functioning but the future prospects of Japanese industry. This kind of commitment between employers and employees is closely interrelated with the system of recruitment, motivation and reward. And definitely indeed, it is a basic part of the entire Japanese factory organization.

\section{B. Recruitment and Selection of Personnel}

\section{1) Basic standard of recruitment}

Japanese factories hold a contradictory view in terms of recruitment and selection of personnel. Due to its lifetime employment relationship, in which employees are supposed to serve in the company for a lifetime on the moment of his graduation from school. Thus, the basic standard of recruitment of Japanese companies is entirely different from American ones.

In Japanese factory, selection of personnel is related closely to education rather than any other consideration. For instance, qualities of individuals and methods of selection are hardly paid attention to. In this way, problems of how Japanese schools are organized, and what the reputations and personnel of the schools will be performed as a foundation for categories of employees selected and arrangement of their future development.

The process of recruitment and selection also show an inherent relation in the broader social system. Such matters, 
for example, employees' family background, relationship with the teacher in colleges, as well as their education level achieved do play a significant role in the process. Still, employers' nepotism and the like are factors should not be forgotten in the employment system of Japanese factory.

In many cases, direct family relations among employees are discouraged and limited in large Japanese companies. Example is given to a marriage relation among employees, most particularly among "Shokuin". Not only does the husband find it negative in a marriage during his career process, but also will the wife be expected to retire.

A survey of one plant showed that about one out of four of the female workers were reported relatives in terms of the employ of the company; and one of four male workers were in both factory and office. The relationship was not often father-son or father-daughter, but in the majority of cases was one of uncle-nephew or uncle-niece [3]. This phenomenon was normal because it was desirable by the family to get a family number in the work situation and the bonds of obligation between brothers help achieve the uncle-niece relations in the plant.

\section{2) Consequences of the recruitment system}

This outline of recruitment and selection process in Japanese factory plays an important role in understanding the factory in two ways. In the first place, the system of recruitment is a part of reinforcement to the effects of the basic system of worker-firm relationships. Moreover, to make an understanding of the methods of recruitment and selection is essential to understand the kinds of relationships within the firm.

At the same time, however, it is impossible to turn a blind eye to the problems derived. Based on the selection standard judging from education, a problem of talent waste performs a major issue. For instance, once a young middle graduate is accepted as a sweeper or a doorkeeper, he will serve till the end of employment because of his lack of education. On the contrary, a college graduate without ability may be placed in a position of an important section.

Another far-researching effect of this recruitment system is due to the disparate groups. Now that are the workers in each group experience and outstanding, they are lack of communication with each other. So this system is in terms of loss of potential leadership in the lower rank.

\section{Rewards and Incentives}

Differences between Western and modern Japanese industry have been highly revealed through the study of reward and incentive system in large Japanese factories especially on the aspects of attitudes and behaviors comparing to the United States. The system will be examined in some fields, the general benefits, welfare activities as well as worker incentive programs. And a typical retirement program also stands in helping make a comparison.

There are two groups of company employees in the firm that Abegglen took as an example in his study: Shokuin and Koin. Particularly, the Koin group is further divided into two types, monthly paid workers and daily paid workers. But those daily paid workers will be promoted to monthly paid group when they have obtained one year's seniority. And all factory labors begin as daily paid Koin here. Though the pay system seems a little complicated, their initial base pay remains a formula. For the Koin, base pay is determined based on workers' ages at the time of entrance; while for the Shokuin, the initial pay is a function of education.

Generally speaking, the pay system rests on the base-pay formula, and the base pay is a function of age and education. Instead of setting by work rank, the work efficiency and the worker's ability to complete works, the base pay only depends on the two factors. To move on further, the base pay is also primarily an exemplification of length of service, where the concept of seniority-based system comes into sight one more time. In other words, the entire salary is based on the employees' educational status on the entrance to the company and the length of time a worker has served, only a small part of the total reward determined by the kind of work and how completed.

The pay system gets far-reaching implications on both systems of production and human relations. Its importance will emerge when Japanese workers are not only provided with direct momentary rewards but a total range of rewards and incentives. Welfare program also contributes a lot to this phenomenon and data has been obtained in another plant that Abegglen took as an example to illustrate the importance in Japanese worker compensation scheme.

Two more items of Japanese welfare program must be noted: 1) the retirement system used in large factories; and 2) the bonus system by which wage level will go up about ten percent. Thus, the problem of retirement age and retirement pay is a serious one for Japanese companies. Japanese management takes a considerable responsibility for the workers as the management attitudes have shown. Though the average retirement for male employees in most large Japanese factories is 55 years old, it differs in employee rank and the retire age of top management is not strictly limited. On the other hand, the retirement pay in this company has been established depending on two factors: first on education and second on the length of service.

\section{Organization and Union}

\section{1) Organizational system}

Most Japanese large firms operate in several locations, but the main office is usually located in one of the large cities, especially in a down-town area. The main office is the center of the firm, laboratories, sales and plants offices throughout the country. The units of organization of the main offices include some departments, and the departments will divided into sections, which are divided into branches. Employees of the company are auditors since rules of governing finance in large firms are substantially less demanding in Japan than in the US. In Japan, there is a tendency for power to be exercised indirectly through symbolic leaders, which may be noted in large companies. And the control function is divided by a senior managing director group and a managing director group. Chiefs of the main office department have equal positions to operating or line managers, which would appear to make for a neat separation of line and staff functions in Japanese factory. To make a summary, there are three main features of main office organization. In the first place, one organization is accurately and elaborately divided into separate groups. The next, formal positions and titles are held 
by a high proportion of persons. The last, the presence of large numbers of deputies and assistants to department and section chiefs has enhanced the complexity of the organization.

The particular importance of highly differentiated organizational system of Japanese factor expresses itself in two aspects. First, in Japanese firms, the organizational system has a certain effect on decision-making process. And the second is the formal organization's relation to the careers of individuals in the organization. The difference between Japanese and the American firm [7], and the relationship between the two social systems and their business organizations are highlighted in the area of decision-making. The consequences of decision-making are also several. First of all, nearly all the decisions are carried out by groups of people in discussions during conferences. The procedure is slow and cumbrous, but it is necessary. The following, communications are not well defined so that decisions have to be transmitted through numerous levels of authority. The last but not the least, in this kind of system, it is impossible to make individual responsibility fixed for decisions or errors in decision-making.

\section{2) Enterprise unions}

Enterprise union is a kind of union organization that unifies all the employees from any job classification. It is an effective function of making the management policy totally penetrated into the organization. And the official of the union trade who are responsible for negotiating with the management will often turn to an executive position for the experience they have gained. In other words, it can be regarded as a process of labor unions changing into enterprise units [8].

In Japan, enterprise unions are composed of core employees, including new staff and middle managers. Even more, enterprise unions cover $80 \%-90 \%$ of the permanent employees in large Japanese corporations. One of the most apparent characteristics is to organize the union mixed with all positions, for example, particular companies who own the qualifications as union members, regular employees in the office, factory workers as well as official staff.

Still, there are problems of those unions. Enterprise union in the workplace has been taken in by the supervising organizations informally and the function is remarkably limited. When facing with a conflict of interest, the standpoint and consciousness as employees instead of union members will be overwhelmingly put into consideration first. Since the conflict among unions is limited by the payment ability of individual companies, gap between the working conditions of union members in each company is being expanded with the development of the labor movement by company.

\section{ARGUMENTS DUE TO DORE: "COMMON DESTINY"}

\section{A. Recruitment and Training}

\section{1) Recruitment and staffing}

There is an important factor for the Japanese factories in recruitment-the educational qualification. In Japan, initial and final educational qualifications are regarded as necessaries throughout the recruitment and Japanese factories usually keep a concordant relationship with universities. On the one hand, new graduates are recommended or dominated by university professors centered in university departments. On the other hand, employees are only valued by their graduation without any individual competences by testing and certifying in professional standards. Recruitment into Japanese factories will be arranged for a general range of work role; however, there is a reasonably clear career progression for all the permanent employees.

Then, the degree is recognized as the ticket-of-entry into managerial ranks. And in Japan, there is only one level or only one tertiary qualification of any significance-a degree taken after 4-year-education in a university. Part-time study for the same degree is probably admitted.

In contrast to the British companies that only want to find a man who fit for the right job, in Japanese corporations nearly all managers are university graduates, the natural way to categorize those managers is in terms of class status rather than education.

\section{2) Training}

Thanks to the great belief in educational qualification, the Japanese factory provides a good deal of continuous in-service training and systematic care to the recruitment of employees. And in turn, this may be a kind of chance to get money back from those who have taken the training courses. The process of training seems a practice of handling persons from one group to another-from schools or families to the firms, to be much vividly, like a traditional marriage transferring a girl to another family.

In Japan, training programs are usually done for those who will use the skills in the firm afterwards. Thus in this way, the return on investment is direct and distinct. It takes on an image of bookish, emphasizing on employees' academic ability. In terms of the training contents, reliance is placed on paper tests, on word written, on articulate cognition and so on. The foreman's medal is competed only by those who have failed the written examinations without any exaggeration. Despite this, a kind of course that aims to impart attitudes and moral principles shows a primary concern of soul. And one more element worth mentioning is that the example taken in Dore's book owns its vocational training school, which the English one has not.

\section{B. Wages}

\section{1) Payment system}

To begin with, everyone here in Japanese factories is paid by month. It is not to say there are not hourly related workers, but their wages are paid monthly through bank accounts. Managers in Japanese factories do not bargain for their salaries because bargain for a rise goes against the whole ethos of the firm. Even if the request is asked, it won't be taken seriously; and even though it is treated seriously, the manager may be questioned for his loyalty to the firm and felt unwanted by the firm.

In order to deal with the problem of how a Japanese wage is made up, four component elements should be examined, 
the basic salary, merit supplement, various allowances and job-level supplements.

First and foremost, basic salary is regarded as a function of seniority-based system. There are agreements on the minimum amount of basic salary that will be received by those joining the firm directly from schools of different levels and by men and women of different ages, 30 for women and 40 for men. Agreement is also made on the speed of promotion from grade to grade by limiting the managerial discretion in wage increases. Education plays a central role in this area that those university graduates receive the most and the higher one goes the faster one will rise. However, this higher and faster principle owns the meaning that between the basic salaries of men and women of identical ages, considerable disparities will develop over the years.

It is well known that the final wage packets have a close relation to the basic salary, but thanks to this grading system, nearly everyone can get a sum of more than two times his basic salary through thirty years' service in the firm. Figures will be shown in the Table III as below.

TABLE III: BASIC SALARIES OF MALE LIFETIME EMPLOYEES (MINIMUM FOR 18-YEAR-OLD MIDDLE SCHOOL GRADUATE=100)

\begin{tabular}{|c|c|c|c|c|c|c|}
\hline \multirow{2}{*}{ Age } & \multicolumn{2}{|c|}{$\begin{array}{c}\text { Middle school } \\
\text { graduate (i.e. } \\
\text { compulsory } \\
\text { education only) }\end{array}$} & \multicolumn{2}{|c|}{$\begin{array}{c}\text { High school } \\
\text { graduate }\end{array}$} & \multicolumn{2}{|c|}{$\begin{array}{c}\text { University } \\
\text { graduate }\end{array}$} \\
\cline { 2 - 7 } & Min & Max & Min & Max & Min & Max \\
\hline 18 & 100 & 121 & 117 & 117 & & 157 \\
\hline 22 & & & & & 157 & 324 \\
\hline 23 & 133 & 160 & 134 & 176 & & \\
\hline 30 & 155 & 209 & 195 & 257 & 198 & 32 \\
\hline 40 & 267 & $317 / 356^{5}$ & 359 & 476 & & \\
\hline
\end{tabular}

Source: Based on Ronald Dore's "British factory-Japanese factory: The origins of national diversity in industrial relations", pp. 98-101.

It is obviously seen from the figures that even the least favored middle school graduates are able to get two-and-a-half times his basic salary at the age of 45 compared to the entrance age of 18 . The premise of this kind of payment, however, exists that the figures only refer to those who had spent all their working life in the firm.

The second immediate factor is the merit supplement, an additional payment of a percentage of the basic salary. This percentage is on the whole determined by superiors' assessment of the workers' merits. Not only for the workers in the lowest range, but also the senior workers with special titles can receive an average value more than their basic salaries. Particularly for the senior managers, the merit supplement judged on month had become entirely notional because the managers were assessed only in the annual round of basic salary increases.

Miscellaneous allowances are also related to person, to the characteristics of the person, but this relation stands less obvious to the company's profits at the moment than their diligence and skills. Example can be seen in the payment of the total cost of rail and bus tickets, but the cost is afforded only beyond two kilometers [9]. Also, family allowances are paid, for the first dependent, for example, the wife, 3,700 Yen

\footnotetext{
${ }^{5}$ The higher figure is the maximum for those who have already been promoted to foreman grades: the lower for whose still in the basic manual or clerical grades.
}

and 3,100 Yen for somebody else per month; and 300 Yen for each of the next four. Therefore, the size of a family seems a reasonable criterion for distributing a large part of the wage bill.

\section{2) A summary}

According to the discussions done above, the differences on wages between the two countries (the Britain and Japan) will be examined on three aspects. First, on wage negotiation, on the British side, the wages of employees and employers are determined by conditions of the market; while for the Japanese factory, wages of part-timers and new staffs are determined by the managers related.

Second factor is the principle of wage distribution. Wage in Britain is related to the market price for special technology, in particular, the level needed, lack of raw materials, and the cost of production. As for the Japanese side, wage has relations with a group of matters-working for a lifetime, seniority, sex, assessment of managers, responsibilities to family and functions of work in the firm.

The third, monetary incentives also play a role in both countries. In Britain, the salaried managers will be rewarded with high salaries to another job; but wage workers are paid depending on their outputs. By contrast, in Japan, monetary incentives do the performance of difference [10]. Monetary incentives are the same to any type of employees, no matter manual workers or managerial; and are consequential outcome of long term with exclusively contingent. Moreover, the assessment involves in different forms that annual assessment is only done in April, and years assessment are done twice a year, in June and December.

\section{Unions and Industrial Relations}

In the early stage of Japanese unions, they formed as they were with less requirement of solidarity and self-sacrificing. And differences can be seen from a view of organizational principles. It preferred to take a bureaucratic organization of formal and rule-governed forms, especially written down by paper and ink.

Union in the Japanese factory admits only employees from the factory itself and the members of union conclude white collar technical and lower-ranking supervisory, managerial workers. All the members, of course, belong to the union of the factory. As basis for the union in Japanese factory, the grass-roots are from workshop department within the factory, and furthermore, it also collects money from its members.

Wage bargain is considered as a main function of unions in both sides, and there is a system for personnel evaluation each. In Japanese union, personnel evaluation system focuses on workers; while the British union takes responsibility for personnel evaluation system.

\section{CONCLUSION}

Taking into account the factors have been discussed above, differences of the three theories lie not only in the elements of wage system but also in their overall awareness.

Viewing from the joint research of Marsden and Dore, same standpoints are done on performance management, characteristics of employment contract, wages and salaries, 
etc; while differences take positions in the field of limits of managerial authority and performance incentives. At the same time, one particularly different point of view made by Marsden and Dore comes into sight: whether the Japanese employment relationship is competitive or cooperative?

Although Abegglen and Dore mention a similar idea of employment relationship, their understanding differs in some way. In the case study made in Abegglen's research, Japanese companies take full responsibilities for continuous salary to all their employees during the employment. Hence, there is no doubt that workers in such companies are often termed "permanent" or "eternal" employees [11]. Compared to America's development in that period, Japan was left behind in that period. Nevertheless, Dore observes Japan's growing through oil shock and comments a bettering Japan and treats English as a control. Therefore, it is said that Dore has seen the figure of the new industrial society's future.

Here, the limitations of theory statement from economic viewpoint once again become visible. The three, however, stand in two groups-economics and business administration, so it is natural that the problems cannot be examined in its entirety.

Hence it is of great significance to seek for an appropriate direction for Japanese employment system and this requires further studies for integrated understanding and its future development. And, this problem will be cleared up as a research task in the future study. And what should be carefully treated is to make sure that the positive parts are encouraged while the negative ones are eliminated as far as possible.

\section{REFERENCES}

[1] H. Shibata, "International human resources management of japanese, america, and european firms in Asia: The roles of headquarters and subsidiaries," Japanese Center for Economic Research, 2006.

[2] D. Marsden, A Theory of Employment System: Micro-Foundation of Social Diversity, Oxford University Press, USA, 1999.

[3] J. C. Abegglen, The Japanese Factory: Aspects of its Social Organization, Glencoe: Free Press, 1958

[4] R. P. Dore, British Factory-Japanese Factory: The Origins of National Diversity in Industrial Relations, University of California Press, 1973.

[5] S. M. Jacoby, The Embedded Corporation: Corporate Governance and Employment Relations in Japan and the United States, Princeton University Press, 2004.

[6] T. Kono and S. Clegg, Trends in Japanese Management: Continuing Strenths, Current Problems, and Changing Priorities, New York: Palgrave, 2001.

[7] K. Okada, "American factory-Japanese factory," Social Science Japan Journal, vol. 4, no. 1.

[8] P. J. Wu, The Historical Study of Japanese Employment System, Chinese Social Science Press, 2007.

[9] Y. Huo, P. H. J. Huang, and N. Napier, "Divergence or convergence: A cross-national comparison of personnel selection practice," Asia Paciffic Journal of Huamn Resource Management, vol. 40, no. 1, pp. 38-54, 2002.

[10] N. Hiwatari, "Employment practices and enterprise Unionism in Japan," in Employment and Corporate Governance, M. M. Blair and M. J. Roe, eds., Washington D. C., 1999.

[11] J. C. Abegglen, $21^{\text {st }}$-Century Japanese Management: New Systems, Lasting Values, Palgrave Macmillan, 2006.

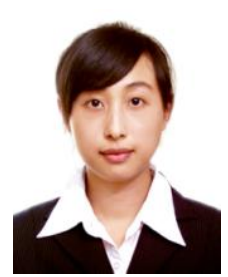

Sun Yan was born in Shenyang, China, on May $27^{\text {th }}$ 1985, has got her BA in Liaoning Normal University, China, majoring in English and International Trade; and an MBA degree in Shiga University, Japan. She is on her second year of the doctoral program in Shiga University, doing a research on the subject of relocation to overseas of Japanese employment system 